\title{
Pengaruh dan Efektivitas Maggot Sebagai Proses Alternatif Penguraian Sampah Organik Kota di Indonesia
}

\author{
Nurcholis Salman ${ }^{1}$, Estin Nofiyanti², Tazkia Nurfadhilah $^{3}$ \\ 1,2,3Program Studi Teknik Lingkungan Universitas Muhammadiyah Tasikmalaya \\ Jl. Tamansari No.KM 2,5 Mulyasari Kec.Tamansari Kota Tasikmalaya, Jawa Barat 46196 \\ *Koresponden email : nurcholissalman@umtas.ac.id
}

Diterima : 11 Desember 2019

Disetujui : 16 Desember 2019

\begin{abstract}
One of the organic waste treatment using the bioconversion process of the Black Soldier Fly larvae or commonly called Maggot. This study aims to determine the total amount of waste produced from bioconversion and to determine the effect of variable type of waste on Maggot growth. The types of samples used are household waste, melon waste, chicory waste and tofu waste as a control. The research method uses the True Experimental Design method with the Posttest Only Control Design research design. The study began with hatching of 1 gram Black Soldier Fly eggs which were then incubated for four days. Analysis of the study was conducted when Maggot was 7 days old with the number of feeding varied per feed. The results showed that total organic waste decomposed varied in each sample, namely the average total waste of 8122.1 grams, 1859.7 grams, 1320.3 grams and 1683.3 grams. The percentage of waste showed $74.6 \%$ for samples without mashed and $87.1 \%$ for mashed samples. The type of waste gives a significant influence on the growth of Maggot the value of sig. 0.024 (sig. P value <sig. Value)

Keywords: Organic Waste, Maggot, Bioconversion, Black Soldier Fly, True Experimental Design

Abstrak

Salah satu pengolahan sampah organik dengan menggunakan proses biokonversi dari larva Black Soldier Fly atau biasa disebut Maggot. Penelitian ini bertujuan untuk mengetahui jumlah total sampah hasil dari biokonversi dan untuk mengetahui pengaruh variabel jenis sampah terhadap pertumbuhan Maggot. Jenis sampel yang digunakan adalah sampah rumah tangga, sampah melon, sampah sawi putih dan ampas tahu sebagai kontrol. Metode penelitian menggunakan metode True Experimental Design dengan desain penelitian Posttest Only Control Design. Penelitian diawali dengan penetasan telur Black Soldier Fly sebanyak 1 gram yang kemudian di inkubator selama empat hari. Analisis penelitian dilakukan ketika Maggot berumur 7 hari dengan jumlah pemberian feeding bervariasi per sekali feeding. Hasil penelitian menunjukan total sampah organik yang terurai bervariasi pada tiap sampel yaitu total sampah rata - rata sebanyak 8122,1 gram, 1859,7 gram, 1320,3 gram dan 1683,3 gram. Persentasi sampah menunjukan $74,6 \%$ untuk sampel tanpa dihaluskan dan $87,1 \%$ untuk sampel yang dihaluskan. Jenis sampah memberikan pengaruh yang signifikan terhadap pertumbuhan Maggot besarnya nilai sig. 0,024 ( nilai sig. $\mathrm{P}$ value < nilai sig. )
\end{abstract}

Kata Kunci: Sampah Organik, Maggot, Biokonversi, Black Soldier Fly, True Experimental Design

\section{Pendahuluan}

Persoalan sampah masih menjadi masalah bagi masyarakat di perkotaan maupun di pedesaan. Tingginya kepadatan penduduk membuat konsumsi masyarakat pun tinggi sehingga meningkatkan penumpukan sampah. Menurut UU no 18 tahun 2008 sampah merupakan sisa - sisa dari segala aktifitas manusia yang berbentuk padat.

Menurut data Dinas Lingkungan Hidup Kota Tasikmalaya tahun 2018 tercatat sampah yang terangkut perharinya sebesar $163.249,68 \mathrm{~kg}$, dengan persentase komposisi sampah anorganik dari pemukiman sebesar 32,16\%, sampah organik sebesar 48,74\%, dan residu sebesar 19,08\%. [1] Sampah organik berasal dari berbagai sektor kegiatan manusia, diantaranya pasar, rumah makan, rumah, hotel dan lain sebagainnya. Dampak negatif yang ditimbulkan dari sampah organik dapat menimbulkan bau busuk dan mencemari lingkungan. [2]

Melihat besarnya jumlah sampah organik yang dihasilkan masyarakat dan dampak terhadap lingkungan, maka perlu adanya pengolahan yang tepat agar sampah organik bisa teratasi dengan baik. Pengolahan sampah organik yang sudah dilakukan dengan dikonversi menjadi pupuk kompos dan biogas 
[3] Selain diolah menjadi kompos dan biogas, daur ulang sampah organik dapat dilakukan dengan metode biokonversi. Biokonversi adalah suatu proses yang melibatkan mikroorganisme seperti jamur, ragi, bakteri dan larva untuk mengubah sampah organik menjadi produk yang bernilai tinggi [4].

Konsep biokonversi dapat menjadi solusi mengatasi masalah pengelolaan sampah organik. "Biokonversi merupakan proses berkelanjutan yang memanfaatkan larva serangga untuk mentransformasi sampah organik. Selanjutnya larva tersebut mengkonversi nutrisi dari sampah dan disimpan sebagai biomassanya" [5].

Lalat jenis Black Soldier Fly mempunyai ukuran lebih besar dari lalat lainnya dan lalat jenis ini tidak menimbulkan penyakit karena masa hidupnya hanya untuk kawin dan bereproduksi. [6] Maggot memiliki tekstur yang kenyal dan memiliki kemampuan mengeluarkan enzim alami sehingga dapat dicerna dan dimanfaatkan sebagai pakan ikan [7]. Maggot dapat mengkonversi sampah serta mengurangi massa sampah 52\%-56\% sehingga Maggot dapat dijadikan solusi untuk mengurangi sampah organik" [8].

Siklus hidup maggot berlangsung kurang lebih 40 hari tergantung pada kondisi lingkungan dan makanan nya. Siklus Black Soldier Fly terdiri dari 4 fase yaitu fase telur, fase larva, fase pupa, dan fase lalat dewasa.[9] Maggot memiliki selera makan yang rakus dan mampu mengurai materi organik dengan sangat baik [10]. Maggot mampu mengeksrak energi dari sisa sisa makanan, bangkai hewan, sisa sayuran, dan lain sebagainya. [11] Maggot juga mampu bertahan dalam cuaca ekstrim dan mampu bekerja sama dengan mikroorganisme lain untuk mengurai sampah organik [12]. Beberapa kondisi yang tidak ideal yang dapat menghambat pertumbuhan maggot antara lain suhu yang tidak optimal, kualitas makanan yang rendah nutrient, kelembaban udara, dan adanya zat kimia yang tidak cocok [13].

Pada tahap prepupa sampai menjadi lalat, Black Soldier Fly akan berhenti makan dan memanfaatkan cadangan lemak yang di tubuhnya sebagai sumber energi [14]. Pada fase prepupa, BSF cenderung mencari tempat yang lebih kering dan pencahayaan yang kurang [15]. Setelah berubah menjadi prepupa, prepupa keluar dari bak yang bersifat basah dan lembab.

\section{Metode Penelitian}

Penelitian ini merupakan jenis penelitian eksperimen yang bertujuan untuk mengetahui jumlah sampah organik yang dapat dikonversi oleh Maggot dan ntuk mengetahui pengaruh variabel jenis sampah pada pertumbuhan Maggot. Penelitian dilakukan di Cigantang Mangkubumi Tasikmalaya. Penelitian dilakukan pada bulan Juni - Agustus 2019.

Alat yang digunakan antara lain wadah plastik, pisau cutter, timbangan digital, bak kayu, alat tulis, label, sarung tangan, jaring nilon. Adapun bahan yang digunakan antara lain sampah rumah tangga, sampah melon, sampah sawi putih, ampas tahu, kotoran puyuh, serbuk gergaji dan pakan ikan.

Metode penelitian menggunakan metode True Experimental Design, desain penelitian yang digunakan adalah Posttest Only Control Design. Dimana kedua kelompok dipilih secara random, kelompok yang pertama diberi perlakuan (X) dan kelompok lain tidak diberi perlakuan [16] Kelompok yang diberi perlakuan disebut dengan kelompok eksperimen sedangkan kelompok yang tidak diberi perlakuan disebut dengan kelompok kontrol. Skema Posttest Only Control Design ditunjukkan pada Tabel 1.

Tabel 1. Skema Posttest Only Control Design

\begin{tabular}{ccc}
\hline Kelompok & Perlakuan & Post test \\
\hline Eksperimen & $\mathrm{X}$ & $\mathrm{O}$ \\
Kontrol & - & $\mathrm{O}$ \\
\hline \multicolumn{4}{c}{ Sumber: Sugiyono (2017) }
\end{tabular}

\section{Variabel Penelitian}

Variabel penelitian adalah sesuatu objek yang mempunyai variasi tertentu yang dapat dipelajari, dianalisis dan ditarik kesimpulannya oleh peneliti [17]. Variabel pada penelitian ini terdiri dari:

1. Variabel bebas (Independence Variable)

Variabel bebas merupakan variabel yang dapat mempengaruhi variabel lainnya, biasa dinotasikan dengan X. Pada penelitian ini jenis sampah yang terdiri dari sampah rumah tangga, sampah melon dan sampah sawi putih merupakan variabel bebas (X)

2. Variabel terikat (Dependen Variable)

Variabel terikat merupakan variabel yang dipengaruhi oleh variabel lain, biasa dinotasikan dengan Y. Dalam penelitian ini, yang menjadi variabel terikat (Y) adalah pertumbuhan Maggot 


\section{Variabel kontrol}

Variabel kontrol merupakan variabel yang yang dapat mempengaruhi variabel terikat, namun dalam penelitian keberadaannya bersifat netral. Pada penelitian ini yang menjadi variabel kontrol adalah ampas tahu. Ampas tahu merupakan limbah dari industri produksi tahu yang dapat dimanfaatkan sebagai pakan ternak. Ampas tahu memiliki kandungan lemak dan protein nabati yang cukup tinggi. Kandungan ampas tahu terdiri dari protein 8,66\%, lemak 3,79\%, air 51,63\%, dan abu 1,21\% [18].

\section{Persiapan Penelitian}

Persiapan penelitian diawali dengan pembiakan telur Black Soldier Fly selama 3-4 hari sejak telur diletakkan. Setelah penetasan, Maggot muda dipelihara selama 6 hari. Persiapan media tumbuh Maggot diawali dengan mengambil sampah organik dari rumah makan, pedagang nasi goreng dan pasar Cikurubuk Tasikmalaya. Selanjutnya sampah tersebut ditimbang dan dimasukan ke dalam bak perlakuan. Sampah organik yang digunakan masih segar untuk menghindari kontaminasi lalat. Sampah organik dan sampah melon tidak dilakukan pencacahan sedangkan untuk sampah sawi putih dilakukan pencacahan. Pakan tambahan sebagai penyuburan menggunakan kotoran puyuh.

Pengamatan penelitian dilakukan ketika Maggot berumur tujuh hari. Maggot umur 7 hari dari inkubator dipindahkan ke bak yang lebih besar untuk memberi ruang pertumbuhan Maggot. Pada tiap tiap bak ditambahkan $1 \mathrm{~kg}$ kotoran puyuh sebagai perlakuan awal dan kultur Maggot.

Pemberian sampah organik sebagai pakan Maggot dilakukan setiap hari dan saat pakan berkurang. Perlakuan kelompok eksperimen berupa sampah rumah tangga dan sampah melon diberikan tanpa dihaluskan terlebih dahulu, namun untuk sampah sawi putih diberikan setelah dihaluskan dan dikurangi kadar airnya. Pada hari ke 21 penelitian, proses pemberian pakan terhadap Maggot dihentikan

\section{Analisis Data}

Data disajikan dalam bentuk tabel dan grafik dan menggunakan analisis uji Kruskal Wallis pada taraf kepercayaan 95\% ( $\mathrm{P}<0,05)$. Data diolah menggunakan program software SPPS.

\section{Hasil Dan Pembahasan}

Pengamatan dan analisis mengenai pengaruh efektivitas Maggot mengurai sampah menggunakan beberapa parameter. Parameter tersebut antara lain pengukuran total sampah yang digunakan, pengukuran pertambahan berat Maggot per tiga hari, pengukuran residu dekomposisi sampah dan pengukuran berat total Maggot.

\section{a. Pengukuran total sampah}

Sampah yang dibutuhkan bervariasi dengan maksimal pemberian satu kilogram per sekali pemberian feeding, maka dari itu frekuensi feeding larva tidak dilakukan setiap hari tetapi dilihat dari habis tidaknya sampah yang diberikan.

Total sampah yang digunakan sebagai media pakan bervariasi untuk setiap sampel penelitian. Ratarata sampah rumah tangga menghabiskan 8.123 gram, sampah melon sebanyak 1.841 gram, sampah sawi putih sebanyak 1.880 gram sedangkan kontrol sebanyak 1.675 gram.

\section{b. Pertumbuhan Maggot}

Pengukuran pertambahan berat dan jumlah Maggot dilakukan tiga hari sekali. Data yang diperoleh digunakan untuk menentukan pengaruh jenis sampah yang diberikan terhadap pertumbuhan Maggot. Pengukuran dilakukan dengan menggunakan timbangan digital, dengan cara mengambil 1 gram Maggot sebagai sampel sehingga diperoleh berapa jumlah Maggot dalam 1 gram seperti Gambar 1.

Sebelum dilakukan penimbangan terlebih dahulu kotoran yang menempel di tubuh Maggot dibersihkan dengan menggunakan tisu. Perlakuan ini bertujuan agar tidak ada kotoran yang menempel di tubuh Maggot tidak mempengaruhi penimbangan berat tubuh Maggot. 


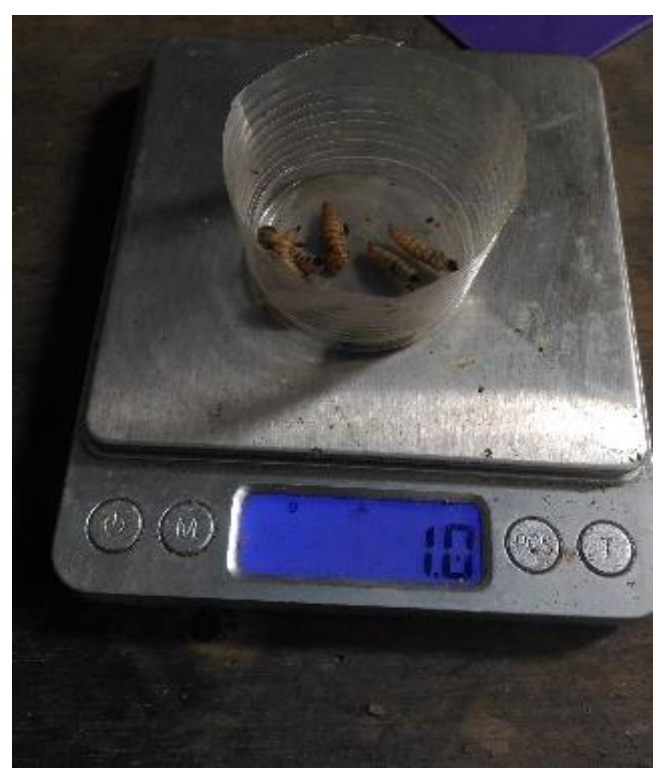

Gambar 1. Penimbangan berat larva

Maggot pada bak sampah rumah tangga mengalami pertumbuhan yang signifikan dikarenakan variasi makanan pada sampah rumah tangga. Pada percobaan hari ke-3 jumlah Maggot dalam 1 gram adalah 15 ekor, 15 ekor, 13 ekor untuk sampel SD1, SD2, SD3 seperti dalam Gambar 2. Pada percobaan hari ke 18 jumlah Maggot berkurang dalam 1 gramnya yaitu 6 ekor, 6 ekor dan 5 ekor, ini menandakan adanya pertumbuhan Maggot. Begitu pun dengan kondisi tubuh Maggot berubah warna dari putih menjadi warna hitam, Maggot pun lebih pasif dalam mengkonsumsi sampah yang di berikan, hal ini menandakan Maggot akan segera menjadi prepupa.

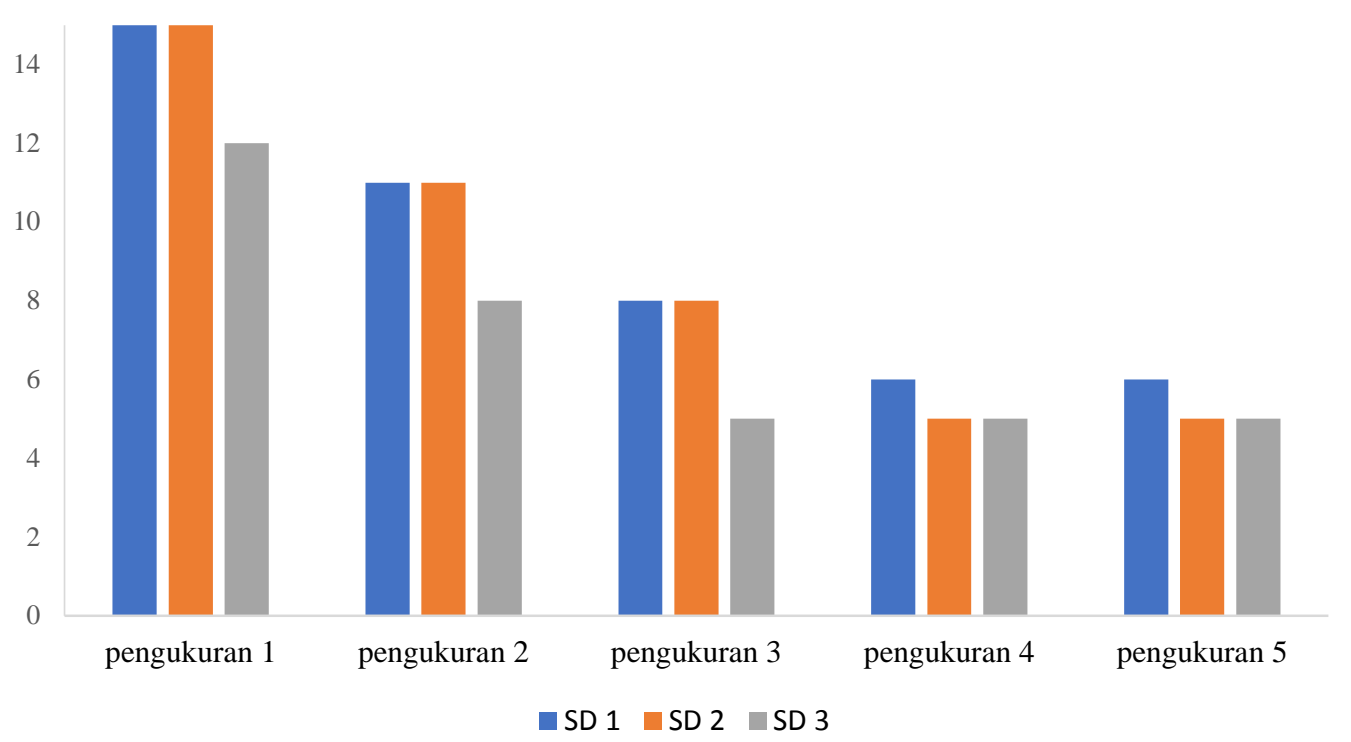

Gambar 2. Grafik pengukuran berat Maggot per 1 gram sampel sampah rumah tangga

Maggot pada sampel sampah melon mengalami pertumbuhan yang cukup lambat. Pertambahan berat tubuh Maggot tidak terlalu signifikan dari awal percobaan. Pengukuran berat Maggot pada hari ke-3 percobaan dalam 1 gram terdapat 21 ekor, 19 ekor, 25 ekor untuk sampel M1, M2, M3 (Gambar 3). Pada hari terakhir percobaan jumlah ekor Maggot berkurang yaitu 16 ekor, 15 ekor dan 17 ekor. 


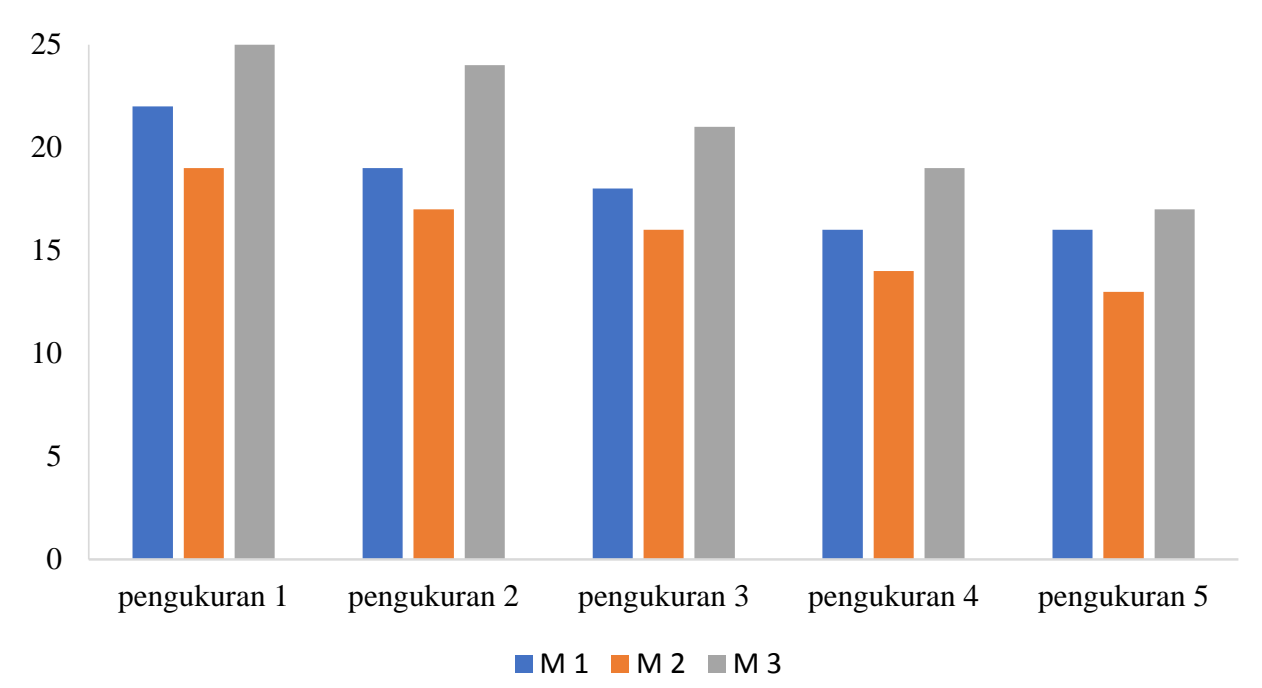

Gambar 3. Grafik pengukuran berat larva sampel melon

Maggot pada sampel sawi putih mengalami pertumbuhan yang lambat. Pada pengukuran pertama pertambahan berat Maggot dalam satu gram ada 27 ekor sampel S1, dan 23 ekor sampel S2 (Gambar 4).

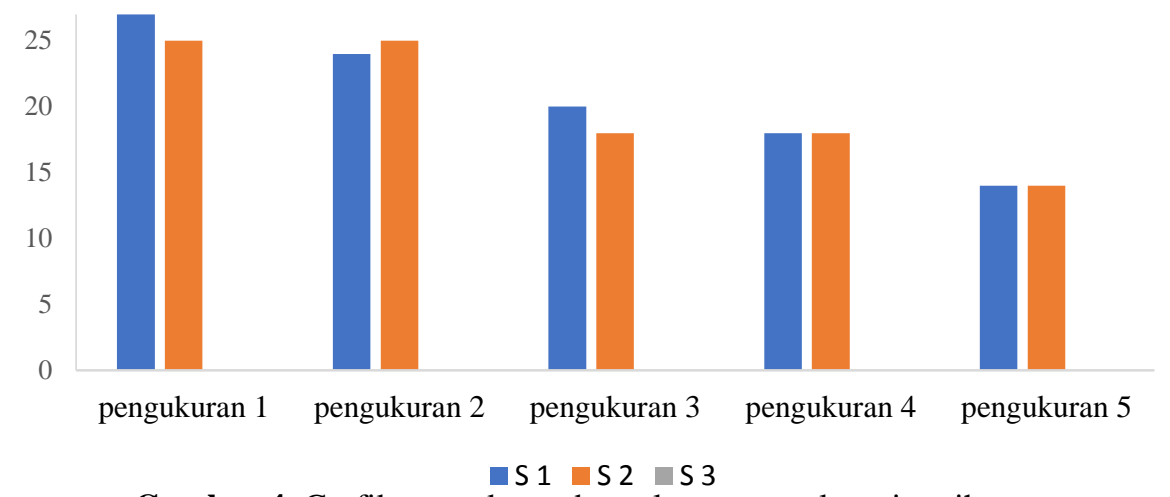

Gambar 4. Grafik pengukuran berat larva sampel sawi putih

Maggot pada sampel ampas tahu mengalami pertumbuhan yang signifikan. Awal pengukuran AT1, AT2 dan AT3 dalam 1 gram terdapat 20 ekor, 19 ekor dan 19 ekor sehingga rata-rata dalam satu gram terdapat 19 ekor, akhir pengukuran AT1, AT2 dan AT3 dalam 1 gram terdapat 11 ekor, 7 ekor dan 7 ekor sehingga rata-rata dalam satu gram terdapat 8 ekor larva (Gambar 5). Fase Maggot pada sampel ampas tahu sangat cepat dibandingkan dengan sampel lainnya, pada hari ke 10 percobaan tubuh Maggot berubah dari putih menjadi kehitam-hitaman. Pada hari ke 14 percobaan Maggot terakhir diberi makan dan di hari ke 15 percobaan dilakukan penimbangan berat total Maggot.

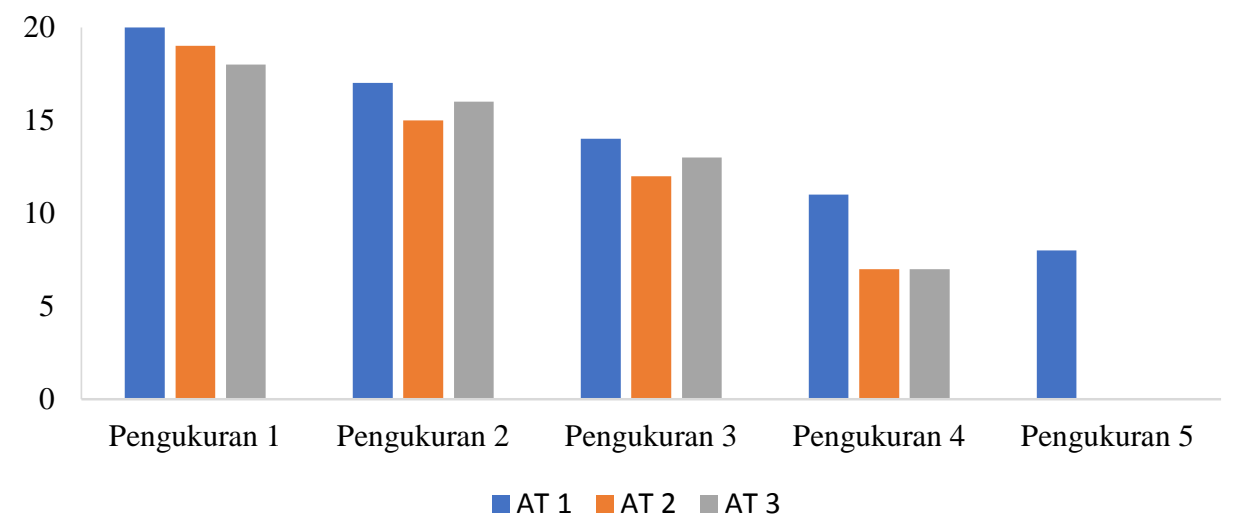

Gambar 5. Grafik pengukuran berat larva sampel ampas tahu 
Pengukuran pertambahan berat dan jumlah Maggot secara akumulasi dari berbagai sampel sampah yaitu sampah rumah tangga, sampah melon, sampah sawi putih dan sampah ampas tahu dapat dilihat pada Tabel 2.

Tabel. 2 Pertambahan berat maggot dari beberapa sampel sampah organik

\begin{tabular}{cccc}
\hline Nama sampel & $\begin{array}{c}\text { Awal pengukuran } \\
\text { 1gr = jumlah Maggot }\end{array}$ & $\begin{array}{c}\text { Akhir pengukuran } \\
\text { 1gr = jumlah Maggot }\end{array}$ & $\begin{array}{c}\text { Total berat Maggot dari } \\
\text { 1 gr telur }\end{array}$ \\
\hline Sampah Rumah tangga & 15 & 6 & 1500 \\
& 15 & 6 & 1700 \\
Sampah melon & 13 & 5 & 1260 \\
& 21 & 16 & 414 \\
Sampah sawi putih & 19 & 15 & 464 \\
& 25 & 17 & 405 \\
Ampas Tahu & 27 & 14 & 275 \\
& 25 & 14 & 278 \\
& 19 & 11 & 1400 \\
& 18 & 7 & 1500 \\
\hline
\end{tabular}

Sumber : Hasil penelitian (2019)

Pertumbuhan Maggot yang signifikan terjadi pada sampah rumah tangga, sedangkan pada sampah melon dan sawi putih pertumbuhan Maggot lambat.

\section{c. Analisis Data Statistik dan Persentase sampah}

Analisis statistik dilakukan dengan menggunakan Kruskal Wallis dimana nilai P Value pada uji Kruskal Wallis ditunjukan oleh Asymp sig, nilai $\mathrm{P}$ Value $<0,05$. Hasil analisis yang telah dilakukan di peroleh bahwa jenis sampah berpengaruh signifikan terhadap pertumbuhan larva dengan nilai $\mathrm{P}=0,024<$ 0,05 .

Persentase didapat dari total sampah dikurangi sisa sampah kering dan Maggot hasilnya dibagi total sampah dikali $100 \%$. Persentase sampah menunjukkan 74,6\% untuk sampel tanpa dihaluskan dan $87,1 \%$ untuk sampel yang dihaluskan.

\section{Kesimpulan dan Saran}

Berdasarkan penelitian yang dilakukan mengenai pengaruh efektifitas larva Black Soldier Fly dalam mengurai sampah organik sebagai alternatif pengurangan sampah kota, diperoleh beberapa kesimpulan:

1. Total sampah yang terurai oleh Maggot sebanyak 8122,1 gram sampel sampah rumah tangga, 1859,7 gram sampel sampah melon, 1320,3 gram sampel sampah sawi putih dan 1683,3 gram sampel ampas tahu.

2. Persentase sampah dengan dihaluskan sebesar $87,1 \%$ dan untuk sampel tanpa dihaluskan $74,6 \%$

3. Hasil analisis statistika Kruskal wallis menunjukkan $0,024<0,05$. Hipotesis yang dari nilai tersebut adalah menerima $\mathrm{H} 1$ dan menolak $\mathrm{H} 0$ atau yang berarti ada pengaruh yang signifikan dari jenis sampah terhadap pertumbuhan Maggot.

4. Hasil akhir berat total Maggot dari 1 gram telur adalah 1500 gram, 464 gram, 278 gram dan 294 gram. Sampel sampah rumah tangga memberikan berat tubuh larva yang paling besar dengan 1500 gram. Maggot sebagai pengganti pakan ternak bisa memanfaatkan sampah rumah tangga sebagai makanannya, ini sekaligus bisa mengurangi sampah kota.

Adapun saran yang diajukan pada penelitian yang dilakukan adalah sebagai berikut:

1. Perlu kajian ulang terhadap porsi makanan yang diberikan kepada Maggot.

2. Perlu dilakukannya suatu upaya mengurangi bau tidak sedap yang ditimbulkan sampah yang sudah terdegradasi. Salah satu upaya adalah dengan mengubah porsi kebutuhan harian Maggot yang tidak berlebihan sehingga proses penguraian sisa makanan dapat di minimalisasi.

3. Perlu dilakukannya penelitian lanjutan mengenai tingkat keasaman makanan terhadap tingkat kematian Maggot.

4. Perlu adanya kajian ulang terhadap makanan yang dicacah dan tanpa dicacah. 


\section{Daftar Pustaka}

[1] Dinas Lingkungan Hidup, 2019. Data persentase komposisi sampah permukiman dan non permukimankota tasikmalaya. Tersedia di Https://data.tasikmalayakota.go.id (diakses 23 Agustus 2019 pukul 20.00 WIB)

[2] Leong SY, kutty SRM, Tan CK, Tey LH. 2015. Comparative study on the effect of organic waste on lauric acid produced by hermetia illucens larvae via bioconversion. J Engineer Sci Technol. 8:52-63

[3] Dian Adijaya S, "Maggot Pakan Alami Ikan Protein Tinggi", (Makalah yang disampaikan pada Bebeja Rujukan Agribisnis Indonesia, 19 Desember 2013), h.25

[4] Pretty Yuniarti Elisabeth Sipayung. 2015. "Pemanfaatan Larva Black Soldier Fly ( Hermetia Illucens) Sebagai salah satu Teknologi Reduksi Sampah di Daerah Perkotaan”. Fakultas Teknik Sipil dan Perencanaan. Institut Teknologi Sepuluh Nopember. Surabaya

[5] Rini Meita Fahmi. 2018. Maggot: Pakan Ikan Protein Tinggi dan Biomesin Pengolah Sampah Organik. Jakarta: Penebar Swadaya

[6] Monita Lena. 2017. Biokonversi Sampah Organik Menggunakan Larva Black Soldier Fly (Hermetia Illucens) Dan EM4 Dalam Rangka Menunjang Pengelolaan Sampah Berkelanjutan. Sekolah Pasca Sarjana Institut Pertanian Bogor

[7] Popa, R dan Green, T. 2012. Dipterra LCC eBook Biology and Ecology of the Black Soldier Fly. DifTerra LCC.

[8] Departemen Pengembangan Sanitasi Air dan Limbah Padat. 2017. Proses Pengolahan Sampah Organik dengan Black Soldier Fly (BSF). Jakarta: Eawag Aquatic research

[9] Apri Hari Wardhana. 2016. Black Soldier Fly (Hermetia illucens) sebagai Sumber Protein alternative untuk pakan ternak. Wartazoa vol.26 No.2 hlm 069-078

[10] Departemen Pengembangan Sanitasi Air dan Limbah Padat. 2017. Proses Pengolahan Sampah Organik dengan Black Soldier Fly (BSF). Jakarta: Eawag Aquatic research

[11] Hartono Rudi. 2008. Penanganan dan Pengolahan Sampah. Bogor: Penebar Swadaya

[12] Kis Dewantoro, S.Pi dan Mahmud Efendi. S.Tr.Pi. 2018. Berternak Maggot Black Soldier Fly. Jakarta Selatan: PT AgroMedia Pustaka.

[13] Suciati Rizkia, Hilman faruq.2017. Efektifitas media pertumbuhan maggot hermetia illucens (lalat tentara hitam) sebagai solusi pemanfaatan sampah organik. Biosfer, J.bio\&Pend.bio. vol 1, No.1.

[14] SNI 19-2454- 2002 tentang tata cara Teknik operasional pengelolaan sampah perkotaan.

[15] Monita Lena et al. 2017. Pengolahan Sampah Organik Perkotaan Menggunakan Larva Black Soldier Fly (Hermetia Illucens). Jurnal Pengelolaan sumberdaya alam dan lingkungan Vol.7 no $3 \mathrm{hlm} 227$ 234

[16] Sugiyono, 2017. Metode Penelitian Kuantitatif Kualitatif dan R\&D. Bandung: Afabeta

[17] SIPSN (komposisi sampah 2017 - 2018) Sistem Informasi Pengelolaan Sampah Nasional Diakses melalui sipsn.menlhk.go.id pada tanggal 23-08-2019 pukul 20.00.

[18] Dinas Peternakan Provinsi Jawa Timur, 2012. Pemanfaatan Ampas Tahu Sebagai Pakan Unggas. Tersedia di https://disnak.jatimprov.go.id (diakses 27 September 2019) 